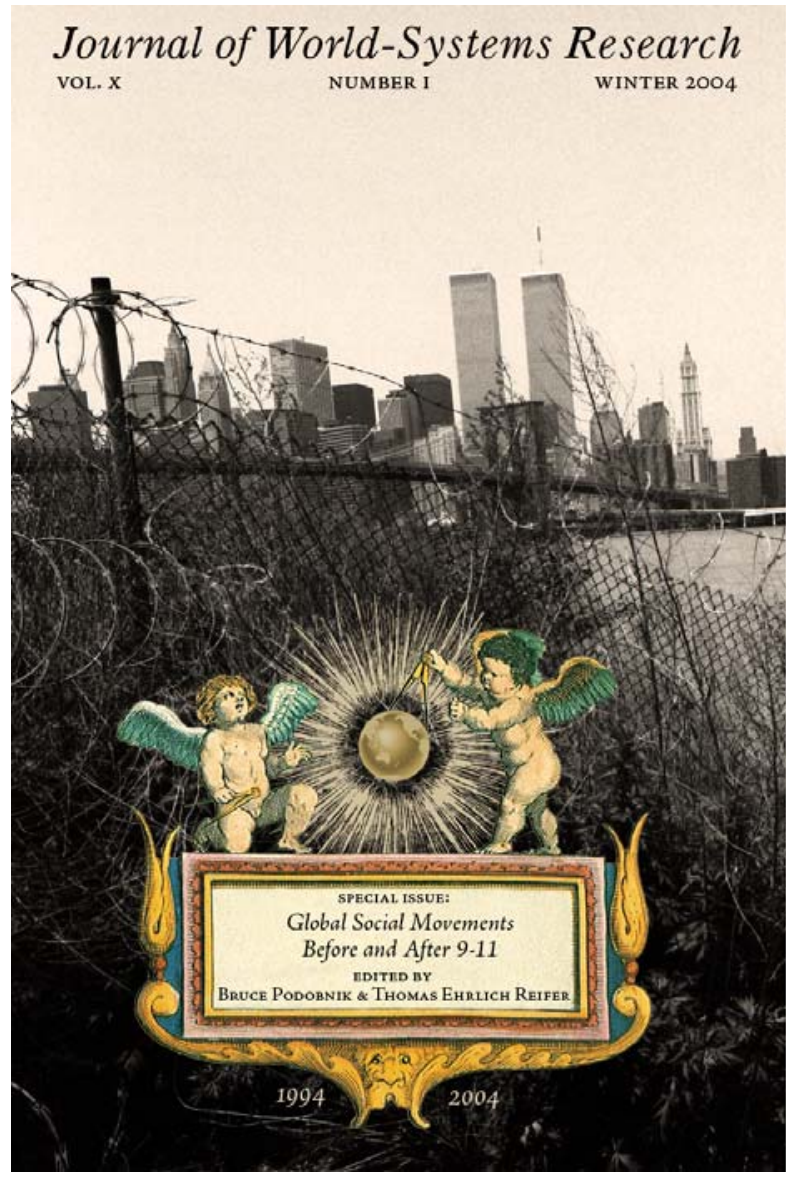

ABSTRACT

With the end of the Cold War, military security issues declined on the internationa agenda as environmental, economic, and socia issues rose. As superpower conflict faded from the international agenda, space was created fo new attempts at multilateral problem-solving. How have these changes affected the prospects for transnational organizing? Using data from the Yearbook of International Associations this paper explores changes in the size, issue focus, geographic makeup, and organizational structure of the population of transnational social movement organizations (TSMOs) in recent decades. While not the only form of transnational cooperation, these formal organizations

\section{Exploring Connections Between Global Integration and Political Mobilization*}

Jackie Smith

$\mathrm{T}$ he Seattle protests against the World Trade Organization and subsequent resistance to global trade and investment negotiations highlight the growing centralization of economic and political power in entities that transcend nationstates. These protests challenge traditional understandings of social movements as bounded by national or sub-national political arenas. Globalization, or the expansion of social interactions across national borders, leaves few areas of social life untouched, and sociologists are beginning to pay closer attention to how it affects our understanding of social and political processes. While globalization is not new, its relatively recent acceleration and expansion to new social domains calls for greater sociological attention. This project builds upon existing sociological research and brings new data to the investigation of relationships between globalization, social movements, and political change.

Jackie Smith

Department of Sociology

Stony Brook University

State University of New York

Stony Brook, New York 11794-4356

jackie.smith@sunysb.edu

http://www.sunysb.edu/sociology/

* This is a revised version of paper presented at the American Sociological Association Annual Meeting, Anaheim, CA, 18 August 2001. This research has been supported by an American Sociological Association - National Science Foundation Funds for Advancing the Discipline grant and by the World Society Foundation. Numerous colleagues provided helpful comments on various aspects of this research, including my colleagues in the sociology department at SUNY Stony Brook, members of the Labor and Globalization seminar at Columbia University, the Globalization study group at the University of Pittsburgh, the Globalization and Contentious Politics seminar at Cornell University, and students and faculty at the Sociology/ Anthropology department at Hofstra University. Special thanks to Dawn Wiest for research assistance on the project and to John McCarthy, Timothy Moran, Sidney Tarrow, Kiyoteru Tsutsui, and Andrea Tyree for comments on earlier drafts.

JOURNAL OF WORLD-SYSTEMS RESEARCH, X, I, WINTER 2004, 255-285 Special Issue: Global Social Movements Before and After 9-II

http://jwsr.ucr.edu/

ISSN $1076-156 \mathrm{X}$

(C) 2004 Jackie Smith 
While many Americans were surprised by the size and vigor of the recent protests against the global trade regime, these events should be seen as part of a long and growing stream of protest against global financial institutions. This resistance has been most visible in the global South, where the effects of global financial policies have triggered the most violent responses. The protests have broadened geographically and gained momentum since the late I970s (see, e.g., Keck 1998; Fox and Brown, 1998; Walton and Seddon 1994). The most recent protests are especially important in that they demonstrate strong opposition to global trade liberalization from a variety of constituencies within the countries that have benefitted the most from liberal trade policies. They also build upon a more extensive network of transnational organizational and informational ties among activists in a wide range of countries. This organizational infrastructure began to expand in the latter half of the $20^{\text {th }}$ century, and its roots took hold and generated more rapid transnational organizational expansion in the I970s and I980s (Sikkink and Smith 2002).

\section{GLOBAL INTEGRATION AND SOCIAL MOVEMENT MOBILIZATION}

How should we expect global integration to impact social movements? Social movement scholars have recognized various potential transnational impacts on social movement mobilization. First, the relative strength or weakness of a state and its degree of vulnerability to domestic political challengers is affected by the state's geopolitical position. For instance, World Systems theory holds that, because of stratification in the global labor market, core states will tend to be more democratic, while periphery states will tend to be more repressive. Thus, the political opportunities that movements in every country face are shaped by how the target government is integrated into the global political economy (see, e.g., Maney 2002; Anderson-Sherman and McAdam 1982; Skocpol 1979). Second, the ideas around which social movements mobilize have long flowed freely across political boundaries. Thus, civil rights activists drew inspiration and strategy from Mahatma Gandhi (Kumar 1992; Chabot 2000) and European and U.S. activists of the I960s learned from each others' experiences and innovations (McAdam and Rucht 1993). More recently, transnational alliances of environmental activists and indigenous groups have generated a "political ecology" frame that relates environmental struggles to concerns for human rights and local empowerment (Rothman and Oliver 2002). Third, transformations in global communication and transportation technologies as well as the related development of global economic and political institutions facilitate the mobilization of transnationally organized social movements (Kriesberg 1997; Guidry, Kennedy, and Zald 2000). ${ }^{1}$ They do so in part by fostering the development of shared cultural and ideological frameworks that serve to legitimate certain collective values and goals - such as democracy, human rights, or free trade - that appeal to global or at least transnational constituencies.

Not only have social movements been affected by changes in the global political and economic order, but they have also played roles in shaping that order. For instance, Keck and Sikkink show how advocates working to abolish the slave trade, helped to advance transnational human rights norms (1998). In addition, numerous case studies have documented that the formation and strengthening of intergovernmental organizations (IGOs) such as the United Nations (UN) have been assisted by efforts of non-governmental actors to shape governmental policies and to codify universal standards for, among other issues, human rights (Hovey 1997; Smith 1995; Boli and Thomas 1999) and more humane military and national defense practices (Evangelista 1995; Finnemore 1996; Price 1998). The recent mobilizations around global trade institutions have built in part upon efforts to defend prior achievements in global environmental, human rights and labor law from growing challenges by the global trade regime (Smith 2002a).

Rates of change in the quantity and speed of economic, political, and other societal interactions have increased dramatically, particularly in more recent times. Forms of economic globalization can be traced back to the late $17^{\text {th }}$ century or earlier (Chase-Dunn and Hall 1997; Wolf, 1982). Political globalization- first characterized by the diffusion of organizational templates for state structures and political organization, and later evolving towards an increasingly organized inter-state polity - dates back at least as far (Boli and Thomas 1997). Socio-cultural globalization developed from the transnational human interactions manifested in economic and political integration. The technological and organizational innovations, particularly those of the late-2oth century, have accelerated capacity for global integration of economic and political activities, and these same innovations have also served to advance globalization of the social and cultural realm.

The changes in all three dimensions of globalization all affect the variable political opportunities available to social movement actors (della Porta and Kriesi 1999). The economic realm is characterized by increasing income dispari-

1. Keck and Sikkink (1998) discuss the formation of less formally organized transnational "issue networks" promoting changes such as the abolition of the slave trade, an end to foot-binding in China, and expansion of women's suffrage. These issue networks resemble what sociologists call social movements, though there are some important conceptual differences, such as a distinction between governmental agents and actors promoting some form of political change (Smith, Pagnucco and Chatfield 1997). 
ties and concentrations of wealth in the hands of transnational corporate actors coupled with the strengthening — particularly during the 1990s—of international institutions designed to facilitate and advance free trade. These developments have important consequences both for the formation of new grievances and for the capacities of challengers to mobilize and to affect social change (See, e.g., Korzeniewicz and Moran 1997; Sassen 1998). In the political realm, the formation and strengthening of supra-national institutions has transferred important aspects of political decision making outside the nation-state. This undermines democratic accountability within states, thereby limiting the abilities of challengers to achieve their goals within national political arenas alone. It has, however, also created new opportunities for social movements and other non-state actors to access decision makers and seek influence in both national and transnational policy arenas (see, e.g., Smith, Pagnucco and Chatfield 1997). ${ }^{2}$

Finally, in the socio-cultural realm, the global spread of ideas (e.g., universal human rights) and cultural materials (e.g., films, music) may help lay the organizational and ideological foundations for transnational collective action. It also creates new incentives for contention as social movement actors seek to align the framing of local conflicts with those of global-level discourses (cf. Snow et al. 1986). By framing local struggles in global terms, local groups can gain legitimacy as well as new international allies. ${ }^{3}$ These various aspects of globalization, in short, affect the political opportunities open to movements at both the national and international levels, the resources available to movement actors, and the interpretations or framings of conflicts. Nevertheless, efforts to understand how global economic, institutional, and social transformations affect possibilities for social movements remain relatively under-developed (but see Tarrow 200I).

2. Kim Reimann (2002) demonstrates how Japanese environmental organizations gained increased access to national politicians as a direct result of the Climate Change Convention negotiations in Kyoto. The international conference increased the salience of environmental issues on national political agendas, and it legitimated the claims of national environmental groups. Moreover, the United Nations practice of recognizing non-governmental actors socialized Japanese officials to expand the access of Japanese NGOs to national political arenas.

3. This does, of course, mean that some of the most urgent struggles are ignored by the international community because they do not resonate with global mobilizing frames (e.g., Bob 200I).

\section{GLOBAL INTEGRATION AND SOCIAL MOVEMENTS: HYPOTHESES}

How are changes in international political and economic interactions likely to affect the mobilization of transnational social movements? Boli and Thomas (1997) documented the presence of a "world polity" that is evidenced by isomorphism in the organizational structures adopted by national states as well as by the global diffusion of ideas such as individualism, scientific rationality, bureaucratization, and citizenship. ${ }^{4}$ They view international non-governmental organizations (INGOs) as important conveyors of world cultural ideas and values, as they seek to promote common international standards for industries or to advance the goals of democracy, human rights, or respect for the environment. Kathryn Sikkink and her colleagues have done important work to demonstrate the ways that certain INGOs advance global norms and shape inter-state politics (Keck and Sikkink 1998; Risse, Ropp, and Sikkink 1999; Khagram, Riker and Sikkink 2002). This wealth of research supports the claim that transnational associations serve as key social infrastructures that help link individuals and national or sub-national groups with global-level political processes. Such a view is consistent with predominant perspectives in the sociology of social movements that treat social movement organizations as key actors within a fluid and loosely organized social movement field (See, e.g., McCarthy and Zald i977; McAdam, McCarthy and Zald 1996). Drawing from this work and others (e.g., Meyer et al. 1997), we would expect to find that:

HI: The size and geographic dispersion of the formally organized transnational social movement sector will expand with increased global institutionalization.

The second half of the $20^{\text {th }}$ century has brought a dramatic expansion of supranational political institutions. Governments have been cooperating around an increasing number of issues-from the rules of war and humanitarian law to environmental practices to the policing of international narcotics trafficking. And they have established formal organizations to structure and routinize this cooperation. This pattern of increased formalization and bureaucratization of (inter-)state structures parallels that accompanying the rise of the modern state. Social movement analysts trace the rise of organized social movements to the

4. The world polity perspective, however, does not account very well for conflicts among these values and how power and politics might affect variation in the reinforcement of certain values (e.g., economic rationalization) over others (e.g. equity, human rights, environmental protection). 
emergence of national states during the $18^{\text {th }}$ century (see, e.g., Tilly 1984; Markoff 1996; Markoff 1999). We should therefore expect greater formalization within a social movement sector that seeks to influence the political contests being waged in emerging supra-national institutions. In other words, just as the rise of states brought with it the emergence of national social movement organizations (SMOs), we should expect an expansion of IGOs to generate new forms of transnational organization, or transnational SMOs.

Early states altered political contests between challengers and elites by bringing a new actor into what once were more regional and local conflicts. That state brought increasing amounts of resources to bear on those conflicts and served as either opponent or ally of local challengers, depending upon the context. The same dynamic is true when we think of the struggles in a global political context. International agencies are created and funded by national governments. They are charged with addressing specific international problems, and they therefore do not always reflect the specific interests of their government members. This creates opportunities for cooperation between international agencies and transnational social movement actors around problem-solving goals. ${ }^{5}$ Such cooperation between SMOs and IGOs can contribute to movement mobilization as well as co-optation.

Once established, international institutions can stimulate growth in the transnational social movement sector by providing access to information and financial resources, by serving as a focal point or target for social movement energies, and by actively facilitating networking among individuals and groups participating in social movements. Beyond its contribution to the overall growth of the transnational social movement sector, we should expect that the character of global political interactions will influence transnational social movement mobilization:

H2: The expansion (or decline) of a particular transnational social movement industry is affected by changes in the broader "world polity." Specifically, growth in a particular transnational social movement industry such as the environment or trade will be associated with new or renewed transnational institutionalization

5. Thus we see that social movement actors promoting limits to greenhouse gas emissions often find ready allies and resources from governments that favor a stronger climate change treaty (including many European governments) and from international agencies (such as the Secretariat for the Climate Change Convention). These allies and resources are part of a broader struggle against other states (e.g., the U.S.) and industry (which created its own "NGO" - called the "Global Climate Coalition"-in order to resist stronger environmental accords). around issues relevant to that industry. On issues where little international cooperation exists, there will be minimal transnational social movement mobilization.

The end of the Cold War meant that superpower rivalries no longer stymied negotiations in the United Nations, creating new optimism for multilateralism. It allowed new issues to achieve greater priority on international agendas, and it opened up space for the emergence of new political blocs. At least at first, this produced new levels of agreement within the UN and generated new treaty initiatives in several issue areas outside of the area of military security. By facilitating cross-national dialogue among actors from both within and outside governments, by focusing government attention and resources on problems defined through international negotiations, and by conveying legitimacy to some of the claims of social movements, international institutions influence transnational mobilization. We should expect, then, that an increase in the numbers of organizations, conferences, and treaties that help structure international political cooperation will affect the shape of the transnational social movement sector.

Another crucial trend in the post-Cold War period is the expansion of neoliberal ideology, including its institutionalization in the World Trade Organization and regional trade associations as well as in the policies of the World Bank and International Monetary Fund. The demise of the Soviet Union was seen as a victory for free market capitalism over socialist economic policies, and proponents of limited government and unrestricted markets enjoyed important influence in the global economic arena. The opening of the World Trade Organization in 1994 clearly altered the context of all multilateral policies, and as the organization took hold, it became clear that its operation could threaten other areas of international cooperation such as human rights and the environment. These developments should be expected to affect the character transnational social movement organizations, probably by attracting greater attention to trade and economic issues.

Economic globalization has important consequences for transnational social movement mobilization; and not least among them is the diffusion of inexpensive communications and transportation technologies which are essential to transnational corporate operations. Does the social movement sector replicate existing structures of economic dominance and marginalization? Are challengers to existing global inequities subject to the same economic forces that reinforce the gaps between the world's rich and poor? The following hypotheses will help organize analyses that address these questions:

H3: On measures of access to IGOs, survival, and legitimacy, TSMOs based in core regions will be more successful than those based in peripheral ones. 
Participation in most transnational political and social change activities demands highly specialized knowledge and skills. At the very least, one is required to speak at least one of the official UN languages. And more ready access to information and officials is available if a TSMO is based near a center of international decision making such as New York, Brussels, or Geneva. Those promoting international human rights must have some expertise in law, and many activists in this area hold advanced degrees in that field. Moreover, the domination of many global institutions by the agendas and interests of core industrialized countries would lead us to expect that the core/periphery pattern is replicated in the social movement sector.

However, the fact that TSMOs are, by definition, challengers to the existing political and economic order, we would expect that they would not simply mirror and reinforce structural inequalities, but rather that they would seek to transform them (Amin et al. 1990). Thus, we expect core/periphery differences in the social movement sector to be shrinking over time, particularly as the sector itself becomes more organizationally rich and diverse. ${ }^{6}$

H4: Core/periphery distinctions found in global economic relationships are reproduced in the political realm, making TSMOs more populous in core areas. Over time, however, as access to transportation and communication increases, as the number of TSMOs expands, and as technology becomes more widely disseminated, the location of TSMOs will be less concentrated in the core.

An additional area of concern regards the ways that changing technologiesparticularly the expansion of electronic communications-affect transnational organizing. We should expect that expanding global integration of social, economic, and political relations both reflects and contributes to new opportunities for transnational organizing of all kinds. Technologies that facilitate transnational communication and routine exchanges of ideas as well as international conferences and exchanges that bring individuals and organizational representatives together help reduce the costs of building and maintaining transnational organizations. They therefore increase the feasibility of individuals' direct participation in transnational organizations, rather than indirect participation through national sections of a transnational federation. At the same time, globalization processes are fraught with uncertainties and rapid change. Anticipating the course of complex inter-state negotiations and the applications of interna-

6. I expect that increased competition for participants and resources among a larger number of TSMOs would encourage their geographic expansion.
Exploring Connections Between Global Integration

tional law poses major challenges for transnational actors, including businesses as well as advocates for social change. In order to avoid unforseen calamities or to take advantage of emerging opportunities, transnational actors must be able to respond quickly. They also must have the capacity to mobilize differently in different parts of the world. Just as businesses must tailor their marketing and industrial strategies to local contexts (see, e.g., Sklair 200I), so, too, must transnational social movement actors cultivate mobilizing strategies that are appropriate to local or regional cultural and strategic conditions. Thus, we would expect to find that transnational movement structures will become more decentralized and informal over the recent decades of expanding global integration.

H5: The structure of transnational SMOs will become more decentralized and informal as new technologies and increasing global social, economic, and political integration facilitate participation by individual members and reduce organizing start-up costs.

\section{METHODS}

Formal organizations provide important infrastructures that aid activists in their efforts to mobilize and act collectively to promote social change. Earlier work suggests that social movement organizations that adopt transnational organizational structures play key roles in mobilizing, informing, and coordinating collective action on issues crossing national boundaries. Thus, this study examines the characteristics of formal transnational organizations advocating for social change. Indicators of this dependent variable - changes in the transnational social movement sector-come from the Yearbook of International Associations (1973, 1983, 1993 and 2000/or editions). ${ }^{7}$ The Yearbook is edited by the Union of International Associations (UAI) in Brussels, which is charged by an early UN Resolution with helping maintain a census of international associations of all kinds. The UAI defines international associations as those with members in at least three countries, and it identifies such groups through a number of mechanisms, including referrals from other organizations, website searches, and self-identifications. It then sends an annual survey to all identified international organizations to update each entry and to assess whether or not a group remains active.

Like any data source, the Yearbook has important limitations, especially when one is interested in tracking groups that may be minimally structured and

7. For more details of the Yearbook and coding procedures, see Smith (1997). 
dependent upon volunteer labor. It also under-represents non-state groups that use violence as a political tactic, since these groups are unlikely to seek inclusion in the Yearbook, for obvious reasons. The Yearbook staff, nevertheless assembles the most complete census of international organizations, and its methods for continuously identifying new groups are rigorous. Moreover, Yearbook editors update their census annually, and they have incorporated Internet searching into their methods. They indicate both newly formed groups for which they have minimal information as well as indications that a group has ceased activity. ${ }^{8}$ Each edition of the Yearbook was reviewed to identify free-standing non-governmental associations that were specifically organized to promote some type of social or political change goal.

In earlier years, the selection process excluded labor unions as well as "Institutes" and "Foundations" in order to limit the possibilities of including groups that may have government affiliations or whose work involves primarily research or funding activities outside the realm of social movement activity. In the 2000 collection process, we included all of these organizations in order to allow us to examine labor groups and to determine how the prior exclusion of such groups influences our understanding of the sector of organizations advocating social change. Of 1064 organizations identified in the 2000/I Yearbook, I06 or I0\% were either labor organizations, foundations or institutes. Most of these (7I\%) were labor organizations. To maintain comparability with earlier years, however, our analysis here is limited to groups that fall under our selection criteria for the earlier periods, thereby excluding these groups. The groups that are included, then are all nonviolent organizations with members in at least three countries that pursue any kind of social change goal. So they range from groups like Amnesty International to the Universal Esperanto League to antiabortion organizations. Development organizations are included in the dataset only if their entry suggests that they advocate for poor empowerment rather than simply provide for the delivery of services.

Once the population of TSMOs was identified, each listing was coded to record information such as the location of the organizational headquarters, the countries of membership, issue-focus, membership structure, and ties with other

8. Such cases are included in separate sections of the Yearbook, including identification numbers to indicate whether a group seems to be an "internationally oriented national group" (e.g., no evidence of transnational decision making or governance), "recently formed" or "apparently inactive." In our selection process, most of the groups in these categories were excluded, except when the author had additional sources of information on the group that warranted inclusion in the dataset. nongovernmental organizations (NGOs) as well as with IGOs. Groups were also tracked between the two time periods so that we could identify which groups that were present in the earlier time period disbanded or were otherwise inactive by 2000 . This tracking across time-periods also identified some groups that were missed in the 1993 selection process, leading us to update the previously reported figures for $1993 .^{9}$ Additional information about the funding sources of TSMOs was recorded for the 2000 period. $^{10}$

Analyses of earlier editions of Yearbook entries showed dramatic increases in the numbers of transnationally organized SMOs, particularly since the early 1970s. They also revealed changes in the broad issues around which people organized transnationally and in the structure of transnational organizations (See Smith 1997; Sikkink and Smith 2002). But the I99os witnessed some major changes in the global system that should have significant impacts on the ways people organize across political borders. The dissolution of the Soviet Union both expanded the number of states formally participating in the international political community and fundamentally transformed the geopolitical context. The Cold War conflict dominated the post-WWII era and severely restricted international cooperation on issues other than security and disarmament. With the end of the Cold War, other issues emerged on the international agenda, and more of the political discourse emphasized the interdependencies of security, environmental, and economic issues. The opening of new "emerging markets" in the former Soviet Union also fueled the expansion of neoliberal economic policies and contributed to the period's rising levels of international trade and investment. At the same time, actors such as NGOs and corporations that had long been in the corridors of international negotiations were seen as growing in importance as global actors, alongside states. And analysts increasingly recognized an enhanced role for international institutions and political processes in shaping all levels of politics (see, e.g., Risse 2000; Risse-Kappen 1995; Tarrow 200I).

9. Similar tracking was done for the earlier periods recorded for 1953, 1963, 1973, 1983, and 1988. Roughly 8-10\% of additional cases were identified by tracing each case from the lists generated in searches of the subsequent edition of the Yearbook back to earlier time periods. Missed cases appeared to be random errors resulting from the process of reading thousands of entries in the Yearbook's small print.

10. This information was not recorded from earlier versions of the Yearbook because we believed the reporting on this measure was too inconsistent, and it was not provided for a large number of entries. The entries for the later periods are much more consistent and complete. 
Table 1: Size and Geographic Dispersion of Transnational Social Movement Organizations*

\begin{tabular}{lcccc}
\hline \multirow{2}{*}{ Year } & \multicolumn{2}{c}{ Number of TSMOs } & \multicolumn{2}{c}{ Numbers of Countries In Memberships } \\
& \# Orgs. & \% Change & Mean (st.dev.) & Median \\
\hline 1973 & 183 & - & $33.89(23.17)$ & 28 \\
1983 & 348 & $90 \%$ & $31.02(26.03)$ & 23 \\
1993 & 711 & $104 \%$ & $33.13(29.55)$ & 23 \\
2000 (observed) $^{* *}$ & 959 & $35 \%$ & $34.39(32.46)$ & 23 \\
2003 (estimate) & $\mathbf{1 0 1 1}$ & $\mathbf{4 2 \%}$ & & \\
\hline
\end{tabular}

* Data for 1973 were colleted in collaboration with Kathryn Sikkink (see Sikkink and Smith 2002)

** To allow for more accurate comparisons between these unequal time periods, the bold figures are estimates derived by calculating the average number of new groups formed each year between 1995 and 1999 and adding three times this average to the total observed in 2000/1.

The current paper asks how the transnational social movement sector changed during a period when the international system itself witnessed a dramatic transformation that included more extensive international and transnational engagement. I begin to explore the hypotheses outlined above using data the transnational social movement sector during the rg9os. While additional case study data are needed to fully test the hypotheses, we can begin here to identify patterns and develop lines of future inquiry into the dynamics of transnational organizing.

\section{DATA}

Hypothesis I anticipates that increasing global integration will both necessitate and create opportunities for transnational mobilization. Given that the end of the Cold War has been accompanied by efforts to expand the agendas and jurisdictions of global political and economic institutions, we should expect to find growth in the numbers of new transnational organizations formed during this period. Also, we would expect that these trends would help already existing groups to mobilize members from more countries.

The data in Table I do not generally support the expectations in hypothesis I. Although we expected to find an acceleration in the formation of new TSMOs during the I99os, in comparison to the growth rates of previous decades, substantially fewer new groups were formed during this later period. Further confirmation of this slowing growth trend is that the average numbers of new organizations formed in the five years prior to each data collection point declined from an average of 21.8 in 1993 to 17.4 in 2000 . Comparisons of the numbers of countries in which TSMOs report members provide little support for hypothesis I. Although the average number of countries with members increased slightly between 1983 and 2000, the median number of countries remains unchanged, as does the average number of continents in which groups report members. Moreover, the increase in the numbers of states in the international system during this time would lead us to expect some increase in the numbers of countries represented in TSMO memberships.

The most plausible explanation for this finding is that we have a saturation effect in the population of TSMOs (see, e.g., Minkoff 1995; Hannan and Freeman 1977). As the density of organizations increases, the competition for resources and members is expected to inhibit the formation of new groups. Given a limited pool of resources and the high costs of transnational organizing, activists seeking to take advantages of new international political opportunities may seek more cost-effective ways of doing this than starting a new international organization. Thus, although the I990s brought a clear change in the "opportunity structure" defined by the international system, these changes could not sustain the high rates of organizational growth that we saw in the 1980s. Nor did they encourage existing organizations to expand significantly their geographic scopes. If the I990s and expanding global integration did indeed provided impetus for more activists to engage in transnational activism, this new activism is not reflected in a growing rate of new international organizational foundings.

While the saturation effect would encourage organizers to find alternatives to starting up new transnational organizations, we could also infer from these data that pre-existing organizational structures were able to respond to the more favorable political conditions of the I990s by expanding to incorporate new members and program agendas. I explore this interpretation further in the discussion of organizational structures below.

I also see an exogenous explanation for the slowed growth of the TSMO population during the I990s. The 1992 United Nations Conference on Environment and Development (UNCED) led to an unprecedented move within the UN system to allow national and sub-national groups to perform tasks that were once the domain of transnational associations. Whereas prior to 1992 formal accreditation at the UN required a transnational organizational structure, the UNCED Secretariat allowed national groups to apply for formal accreditation to the conference, and this precedent led to the adoption of similar rules in other UN venues. ${ }^{11}$ Before 1992, national groups seeking to work within the UN

11. Formal accreditation at UN Conferences enables organizations to have access to official proceedings, provides access to official documentation surrounding the meeting, 
Table 2: Issue Focus of Transnational Social Movement Organizations Number of Organizations (Percentage)

\begin{tabular}{|c|c|c|c|c|}
\hline & $\begin{array}{c}1973 \\
\mathrm{~N}=183\end{array}$ & $\begin{array}{c}1983 \\
\mathrm{~N}=348\end{array}$ & $\begin{array}{c}1993 \\
\mathrm{~N}=711\end{array}$ & $\begin{array}{c}2000 \\
N=959\end{array}$ \\
\hline Human Rights & $41(22 \%)$ & $89(26 \%)$ & $200(28 \%)$ & $247(26 \%)$ \\
\hline Environment & $17(9)$ & $43(12)$ & $126(18)$ & $167(17)$ \\
\hline Peace & $21(12)$ & $37(11)$ & $82(11)$ & $98(10)$ \\
\hline Women's Rights & $16(9)$ & $25(7)$ & 64 (9) & $94(9)$ \\
\hline Development/empowerment & $8(4)$ & $15(4)$ & $52(7)$ & $95(10)$ \\
\hline Global Justice/Peace/Envir. & $7(4)$ & 13 (4) & 30 (4) & $109(11)$ \\
\hline Self-determination/Ethnic unity & $13(7)$ & $26(7)$ & $25 \quad(3)$ & $20(2)$ \\
\hline Right-wing** & - & - & $9(1)$ & $16(2)$ \\
\hline Multi-issue organizations* & $18(7 \%)$ & $43(12 \%)$ & $82(12 \%)$ & $161(17 \%)$ \\
\hline
\end{tabular}

* This categorization overlaps some of the categories above- especially the global justice category.

${ }^{* *}$ Because many right-wing organizations are secretive otherwise averse to making information about their work widely available, such groups are likely to be under-reported in the Yearbook. The most recent issues of the Yearbook rely in part on searches of organizational websites, and therefore have been able to include more of these types of groups that are unlikely to respond to requests for information.

system needed to develop an affiliation with a transnationally organized group that had official accreditation. However, the UNCED process opened the door for national groups to develop direct contacts with UN offices. This change in the broader political environment certainly contributed to the slower growth of transnational associations by reducing the need for nationally based activists to join in formal international alliances.

The second hypothesis was that the changed global political context of the I99os would shape the issues around which people organize transnationally. Specifically, as global institutions expand their scopes and as global conferences sponsored by the United Nations encouraged mobilization around particular issues, ${ }^{12}$ we expected to find changes in the way social movement actors frame

and provides limited speaking rights in official, inter-governmental meetings. Immediately following UNCED, national and sub-national groups were granted the rights to participate formally in the annual Commission on Sustainable Development, whose role was to monitor national governments' follow-up to UNCED. Other UN agencies followed this precedent as they re-evaluated their $\mathrm{NGO}$ accreditation process.

12. The UN sponsored an unprecedented number of such conferences during the I990s on issues ranging from environment and development (1992) to womens' rights (1995) to housing (1997) and population (1994).
Exploring Connections Between Global Integration

their own struggles. Table 2 displays the issues around which TSMOs organized during 1993 and 2000.

We find here that human rights remains the major issue around which the largest numbers of TSMOs organize, and a consistent quarter of all groups work principally on this issue. The environment has attracted growing attention since the early I970s. And between 1983 and 2000, development issues motivated a larger percentage of TSMOs. This parallels a growing international discourse on development and inequality that intensified with the end of the Cold War. Many analysts characterized the shift from Cold War to post-Cold War politics as one from East-West to North-South conflict, as negotiations on trade liberalization and development displaced attention to arms control. Most UN Conferences reflected the economic divisions between the global North and South, as many global problems were linked to enduring inequalities and development failures. A growing emphasis among TSMOs on development is consistent with the hypothesis that the sector is shaped by changes in the broader global polity.

A robust trend we see in the I990s is a shift towards more multi-issue organizing by TSMOs. The number of groups adopting multi-issue organizing frames doubled between 1993 and 2000 . Interestingly, groups organized within the global South were significantly more likely to engage in multi-issue organizing. ${ }^{13}$ This would suggest that Southern TSMOs face different mobilizing opportunities and constraints from their Northern and trans-regional counterparts. Such differences may arise from more repressive political contexts that foster frames that approach highly contentious issues such as equity and human rights from less confrontational angles. One such example would be the Greenbelt Movement in Kenya, which originated as a women's tree-planting organization and subsequently expanded its frame to issues such as empowerment and equitable development (See, e.g., Michaelson 1994). Also, groups in the South often aim to cultivate ties with Northern counterparts in order to bring external financial and symbolic resources for their struggles. This may mean that they must adapt their frames to fit those that resonate with Northern audiences. Most prominent among these kinds of cases are indigenous rights groups that extend or bridge their issue-frames to demonstrate connections between human rights and

13. Twenty-six percent of groups organized in the South indicated a multi-issue organizing frame, compared to $17 \%$ of North- only and trans-regional (e.g., both North and South) organizations $(\mathrm{p}<.05)$. The North-South differences here are mirrored in two surveys of transnational human rights and environmental organizations (see Smith 2000). 
environmental degradation (See, e.g., Brysk 1996; Rothman and Oliver 2002). Another possible explanation is that populations in the South face experiences that make the connections between global economic divisions and other issues much more obvious. Under such conditions, organizing for peace or human rights without explicitly identifying the underlying economic sources of conflict would be ineffective.

Another trend towards greater multi-issue frames is reflected in the growing numbers of groups organizing around a broad global justice/peace/environment frame. Such groups grew from just $4 \%$ in the early 1990 s to II\% by 2000 . This pattern may lend credence to my latter interpretation of the causes of more frequent multi-issue organizing in the global South, assuming that the intensification of global economic integration during the I99os would more broadly reproduce the kinds of experiences faced in the global South that clarify connections between economic inequalities and other problems. This development also parallels expanding multilateral cooperation on trade issues that characterizes the post-Cold War period.

The issue of ethnic unity/ liberation drew declining attention as the organizing focus of TSMOs. The most recent period again saw a decline in the absolute numbers of such TSMOs from 26 to 20 . This can signal two very different trends. One is that these types of movements are adopting-probably in response to the elimination of Cold War induced transfers of military aid-more militant, illicit tactics and therefore are less likely to report their activities in the Yearbook. Another possibility is that activists are framing ethnic struggles in new ways in response to changing issue priorities on the international agenda. Rather than advocating separatist goals, for instance, they may seek to create more inclusive, transnational identity categories such as indigenous peoples or refugees. Such identities allow groups to take advantage of opportunities in international institutions that legitimize individual human rights claims and challenge traditional notions of state sovereignty based on self-determination (see Sassen 1998:22). For instance, groups like the Federal Union of European Nationalities or the World Council of Indigenous Peoples may help focus the efforts of multiple different ethnic groups around the aim of using global institutions to protect minority groups' rights against infringements by states and other actors. The data here support this interpretation. About half of the groups working to promote indigenous peoples' rights were formed during the 1980s. Another organizing frame that may be displacing the ethnic unity/liberation one is the anti-racism/ minority rights frame. Half of the groups listing this as a key goal were formed after I980, and one quarter were formed during the I990s.

Peace issues continued to be the focus of organizing for a consistent percentage of groups, despite the dramatic changes in the geopolitical situation following the Cold War. And women's issues are also the focus of a consistent percentage of TSMOs. Finally, I include in the table the groups organizing around right-wing issues, although the figures for these groups are much less reliable, given that many of them operate covertly and are unlikely to make information about their associations available to the Yearbook editors. The Internet has allowed the UAI to expand their own capabilities for identifying and including information about international associations, and this may be one reason why we identified more right-wing groups in the more recent period than in previous ones.

The next hypothesis begins to take up questions about how the structure of the international system may be affecting transnational organizing patterns. Hypothesis 3 anticipates that TSMOs operating in core countries will have greater access to IGOs and will reap advantages of greater legitimacy as well as higher survival rates. We measure legitimacy here in terms of the extent to which an organization maintains links with other NGOs well as with inter-governmental agencies. In addition, the number of different nationalities an organization incorporates into its membership also reflects and contributes to the recognition of the group's ability and its worthiness of respect. We distinguish between internal and external legitimacy, since recognition by one's peers may not translate into respect and recognition from outside actors (for a similar use of this concept of legitimacy see Edwards and Marullo 1996). Table three displays measures that will help us test this hypothesis.

The results in table three are mixed, and they don't allow us to either accept or reject hypothesis 3. The only finding that corresponds with the hypothesis' predictions is that groups whose members were only from periphery countries were less likely to survive between 1993 and 2000 than were groups based in core countries. Organizations that transcend the North-South divide were the most successful at gaining access to IGOs, legitimacy, and consequently at survival. Contrary to hypothesis 3 , South-only groups were more likely than their Northern counterparts to maintain formal consultative status with IGOs and to achieve both internal and external legitimacy. ${ }^{14}$ They had consistently higher numbers of links with other NGOs and with IGOs than their North-only counterparts.

14. Caution must be used when comparing these figures for country memberships, since South-only groups may draw from a much larger number of countries than Northonly ones. We are in the process of developing a more comparable measure for this concept. 
Table 3: Access, Legitimacy and Survival: Comparisons of Core- and Peripherybased TSMOs

\begin{tabular}{|c|c|c|c|c|c|c|}
\hline \multirow[t]{3}{*}{$\begin{array}{l}\text { Scope of } \\
\text { Member Base }\end{array}$} & \multirow[t]{3}{*}{$\mathrm{N}$} & \multirow[t]{3}{*}{$\begin{array}{l}\text { Formal Consult. } \\
\text { Status w/IGOs }\end{array}$} & \multicolumn{3}{|c|}{$\begin{array}{l}\text { Legitimacy } \\
\text { mean (s.d.) }\end{array}$} & \multirow[t]{3}{*}{$\begin{array}{l}\text { Survival } \\
1993-2000\end{array}$} \\
\hline & & & \multirow{2}{*}{$\begin{array}{c}\text { Internal } \\
\text { NGO } \\
\text { links }\end{array}$} & \multicolumn{2}{|c|}{ External } & \\
\hline & & & & $\begin{array}{l}\text { IGO } \\
\text { links }\end{array}$ & $\begin{array}{l}\text { \# Country } \\
\text { members }\end{array}$ & \\
\hline South Only & 65 & $40 \%$ ** & $5.4(6.1)^{\star *}$ & $2.3(2.4)^{* *}$ & $16.8(15.5)^{\star *}$ & \\
\hline North Only & 105 & $19 \%$ & $3.1(4.7)$ & $1.0(1.5)$ & $10.7(5.6)$ & \\
\hline Both N. \& S. & 369 & $41 \%$ *** & $5.9(8.3)^{\star * * *}$ & $3.1(5.3)^{* * *}$ & $42.0(30.7)^{\star * *}$ & \\
\hline 2000 & & & & & & \\
\hline South Only & 77 & $49 \% *$ & $6.3(6.4)$ & $3.2(2.9)^{\star *}$ & $16.3(11.9)^{* *}$ & $69 \%$ \\
\hline North Only & 182 & $34 \%$ & $4.8(6.8)$ & $2.0(2.4)$ & $12.1(7.3)$ & $82 \%$ \\
\hline Both N. \& S. & 491 & $46 \%$ & $7.7(10.0)^{* * *}$ & $3.7(6.4)^{* * *}$ & $44.9(34.4)^{* * *}$ & $87 \%^{* * *}$ \\
\hline
\end{tabular}

* T-test comparisons of means for North only vs. South only groups significant $(p<.05)$.

** T-test comparisons of means for North only vs. South only groups significant $(\mathrm{p}<.01)$.

*** T-test comparisons of means for "Both North and South vs, groups in North or South only significant $(\mathrm{p}<.01)$.

**** T-test comparisons of means for "Both North and South vs. groups in North or South only significant $(\mathrm{p}<.05)$.

Can this be taken to mean that TSMOs have been able to overcome structural inequalities that are entrenched in the global system? Probably not. Ties with international organizations or other external actors are a way for relatively weak groups to increase their access to resources and otherwise enhance their ability to act in the global political arena (see, e.g. Bob 200I). So, the data in Table 3 may nevertheless be reflecting weakness as much as strength. First, groups in the North enjoy greater direct access to and influence on the major power (e.g., core) governments, thereby affecting the course of most major policy decisions even without substantial ties to global institutions. Southern activists are doubly disenfranchised, since their home governments are often less open to democratic influences and less able to affect the course of international policy. They are therefore more reliant on transnational alliances.

Ties with external actors can also be interpreted as a weakness because they can undermine the autonomy of an organization. While no effective social movement organization can succeed if it seeks complete autonomy, organizational survival and, to some degree, effectiveness depends upon an organization's abilities to decide and pursue a course of action around which its members are united. If a
Table 4: North-South Comparisons of TSMO Mobilization

\begin{tabular}{lllll}
\hline & $\mathbf{1 9 7 3}$ & $\mathbf{1 9 8 3}$ & $\mathbf{1 9 9 3}$ & $\mathbf{2 0 0 0}$ \\
\cline { 2 - 5 } & $(\mathrm{N}=135)$ & $(\mathrm{N}=343)$ & $(\mathrm{N}=711)$ & $(\mathrm{N}=946)$ \\
Headquarters Located in: & $48 \%$ & $31 \%$ & $26 \%$ & $28 \%$ \\
Global City & 35 & 48 & 46 & 45 \\
Other Western Europe or U.S. & 12 & 17 & 23 & 21 \\
Global South & & & & \\
& $(\mathrm{N}=132)$ & $(\mathrm{N}=210)$ & $(\mathrm{N}=539)$ & $(\mathrm{N}=750)$ \\
Members located in: & $5 \%$ & $9 \%$ & $12 \%$ & $10 \%$ \\
South Only & 16 & 21 & 20 & 24 \\
North Only & 79 & 70 & 68 & 65 \\
Both N. \& S. & & & & \\
& $(\mathrm{N}=132)$ & $(\mathrm{N}=214)$ & $(\mathrm{N}=534)$ & $(\mathrm{N}=750)$ \\
& $89 \%$ & $87 \%$ & $84 \%$ & $86 \%$ \\
Western Europe & 72 & 64 & 66 & 62 \\
N.America (U.S./Canada only) & 53 & 43 & 49 & 56 \\
Eastern Europe & 84 & 79 & 80 & 76 \\
Any Global South Country & & & & \\
\hline
\end{tabular}

* "Global City" is derived from Sassen's term (1991) and refers here to Brussels, Geneva, London, Paris, and New York.

group has to respond to financial incentives or other pressures from external allies or international agencies, its ability to define and pursue its original goals may be compromised. Also, while many international agencies share TSMO goals like environmental protection, equitable economic development, and demilitarization, they are still under the control of collections of states. They often aid groups by providing resources and information and by advising organizers about how best to influence multilateral negotiations. But they may also deliberately seek to co-opt or at least assuage challengers. At the very least they can serve to channel protesters' energies towards institutionalized forms of action (e.g. efforts to monitor and/or shape international treaties), thereby displacing more radical critiques and disruptive forms of protest. The speculative nature of my interpretation of Table 3 suggests a need for more detailed case study research to uncover the complex relations between intergovernmental and non-governmental organizations (e.g., Friedman et al. Forthcoming; Cullen 2003).

Another way to approach questions about how structural power impacts the transnational social movement sector is to ask whether organizations tend to be based in places that favor already privileged, core groups or whether they 
are accessible to activists in areas outside the core. Hypothesis 4 anticipates that world system relations will affect the locations of TSMOs by encouraging the location of groups in core countries. Table 4 displays comparisons of TSMOs in 1993 and 2000 to determine the extent to which TSMOs are centered in core versus periphery countries.

The patterns in Table 4 generally support the notion that one's location within the world system affects access to TSMOs as well as other resources. The vast majority of TSMOs are headquartered in core countries, and even within those countries, they are concentrated in key cities that serve as headquarters for global political institutions and commerce. Just as Sassen (1991) found global cities emerging from the foundations of communication, transportation, and labor infrastructures that tend to be concentrated in important urban centers, we see a "global city" effect in the political realm as well, as transnational advocacy groups find advantages to being near the headquarters of international agencies. However, the tendency of TSMOs to locate their headquarters in one of five major global cities appears to be declining somewhat. In 1973 nearly half of all TSMOs were based in such cities, but this figure dropped to around one quarter by 1993. The 2000 figures show little change from 1993, but if anything they suggest a reverse, or at least a leveling-off, of the earlier trends towards more decentralization of TSMOs and a greater presence in the global South. ${ }^{15}$

The patterns of regional North-South organization suggest that there may be some movement towards greater intra-regional organization, and that this tendency is most pronounced in the global North. About a third of all groups were organized within either the global North or the South in 2000, whereas this figure was around one-fifth of all groups in 1973. There has been a parallel decline in the percentages of groups that organize across North and South. Comparisons of the mean age of groups that were intra-regional versus transregional amplified this pattern. Seventy-one percent of TSMOs formed before 1990 , and just $51 \%$ of groups formed after 1990 , were trans-regional $(t=4.92)$. The mean age of intra-regional groups was 18 , while the age of trans-regional groups

15. This finding might be the result of a longer lag-time between Northern and Southern groups in the reporting of new organizations in the Yearbook. Because the Yearbook editors are based in Brussels and rely heavily on electronic communications and inter-personal networks to identify new groups, organizations in countries with less developed communication infrastructures and less contact with global institutional forums may not appear in the Yearbook until years after they have been founded. Further research must be done to determine the extent to which this is the case. (I am grateful to Gillian Murphy for raising this observation). was $32(t=7.59)$. Of groups formed before $1980,78 \%$ were trans-regional, but this figure declines to $56 \%$ for groups formed after 1980 . The overall number of transregional groups, however, is growing, so we cannot say that regional organizations are completely displacing more universal ones. Rather, it suggests a shift in transnational organizing strategies.

Boli and Thomas's analysis of the more general category of INGOs showed a similar, growing tendency for these groups to organize along regional lines. They argued that regional organizing enjoyed the "practical advantages of shared language, culture, and history as tools for mobilization with respect to the larger world" (1999: 3I). In their view, the broader world culture and its institutional artifacts define an overarching framework within which "world culture authorizes and compels organization at diverse levels" (1999: 3I-2). Thus, the formation of regional groups has been shaped by the UN global conferences, where negotiating contexts encouraged efforts to build broad consensus among NGO participants. Regional organizing also facilitates consensus-building in global NGO arenas, since activists first work through their differences in more localized contexts where the interests of participants are likely to converge and where power differentials are minimized. In global settings, regional spokespersons can represent the views and interests of their regions as they work with their counterparts to achieve a broader consensus. This interpretation would suggest that regional organizations complement rather than compete with the work of broader TSMOs by helping to bridge local- and regional- level concerns with broader international processes. In other words, such groups appear to be mobilizing new constituencies into transnational political arenas.

The vast majority of TSMOs have members in Western Europe and North America. But a comparable percentage of groups have members in the global South, and these percentages have not changed significantly over the past few decades. Citizens from Eastern Europe and the Middle East remain least integrated into the transnational social movement sector, with participation in about half (or less in the case of the Middle East) of all TSMOs, whereas Latin American and Asian rates of participation rivaled that of North America in the most recent time periods.

I want to explore further the unanticipated finding of greater intra-regional organizing among TSMOs in the most recent time period. If this reflects a trend among transnational organizations, it could substantially influence the ways that global interests and conflicts are articulated, particularly if intra-regional groups are not, in turn, serving as bridges that help aggregate and process regionally defined interests and positions into trans-regional (e.g., North-South) groups. Table 5 examines the issue focuses and age of organizations according to their geographic scope. 
Table 5: Issue Focus of Sub-Regional vs. Trans-Regional Organizations

\begin{tabular}{lccc}
\hline & $\begin{array}{c}\text { North-Only } \\
\mathrm{N}=\mathbf{2 1 1}\end{array}$ & $\begin{array}{c}\text { South-Only } \\
\mathrm{N}=\mathbf{8 7}\end{array}$ & $\begin{array}{c}\text { Both North \& South } \\
\mathrm{N}=531\end{array}$ \\
\hline Age (Mean, years) & 18.6 & 17.5 & 32.6 \\
(Median) & 12 & 13 & 22 \\
Formed during 1990s & $45 \%$ & $36 \%$ & $20 \%$ \\
Human Rights & $26 \%$ & $28 \%$ & $21 \%$ \\
Environment & 18 & 7 & 16 \\
Peace & 8 & 5 & 11 \\
Women's Rights & 6 & 17 & 8 \\
Development & 8 & 16 & 9 \\
Global Justice/Peace/Environment & 11 & 17 & 10 \\
Self Determination/Ethnic Unity & 1 & 1 & 3 \\
\hline
\end{tabular}

The results in Table 5 indicate that the tendency of groups to organize within their particular geographic region of North or South is a recent one. Of all groups formed during the I990s, more than half adopted intra-regional organizational structures. Forty-one percent of groups formed during the I99os were North-only groups, and an additional $13 \%$ were South-only groups. Forty-six percent of all groups formed during this recent decade transcend the NorthSouth divide. Moreover, the shift towards more intra-regional organizing within both the global North and South may be reflecting more deep-seated cleavages across geographical divides. In areas where the North-South conflict is most pronounced, i.e., where the conflict centers most directly on resource-use questions, the tendency is that we find more intra-regional groups forming as opposed to trans-regional groups that include members from both North and South. Thus, higher percentages of South-only groups focused on development and economic justice, whereas a higher percentage of North-only groups focused on the environment, which is often portrayed as an issue that is at odds with economic development. More North-only groups also focused on peace issues, perhaps because for some Southern groups this may be seen as a lesser priority behind immediate material needs. The fact that a larger percentage of South-only groups focused on women's issues further supports this interpretation, as most women's groups tend to address the development inequities faced by women as a consequence of their differential legal protections.

The greater tendency of Southern groups to work within multi-issue frameworks suggests that such groups tend to favor a different strategic orientation from their Northern counterparts. Whereas Northern organizations may prefer to organize around single-issues for the purposes of political expediency, Southern activists may see such compartmentalized approaches as avenues that avoid addressing fundamental questions about power and access to resources (see, e.g., Steiner 1989; Smith 2002b). A long-time scholar and activist from the global South, Walden Bello, makes a similar observation about these differences in how Northern and Southern activists frame their struggles (Bello 200I). Case studies of specific campaigns show that the North-South differences we observe here may a changing feature of transnational organizations. Northern activists have had to alter the ways that they conceptualize conflicts if they hope to succeed in building ties with Southern activists, which they must do in order to increase their political leverage and legitimacy. Analysts have documented a slow and conflict-ridden process of dialogue and re-framing of conflicts as activists experience new opportunities for transnational dialogue and exchange. For instance, environmental organizations such as Greenpeace, World Wildlife Fund, and Rainforest Action Network have learned - through their contact with Southern activists - to emphasize the links between environmental degradation and the protection of human rights (e.g., Brysk 1996; Rothman and Oliver 2002; Warkentin 2000). And the experiences of organizations working for sustainable development show that interactions between activists in the North and South led to an "unmaking" of Western development framework and a remaking of an alternative (Warkentin 2000:139, see also Macdonald 1997). Annelise Riles's study of Fijian womens' activists provides additional evidence of a learning process within transnational organizations:

Where delegates at previous meetings had been acrimoniously divided over whether structural adjustment or the Palestinian liberation were in fact women's issues,'... at this meeting Fiji's participants in the academic women's networks from 'the South' who had led the fight for the expansion of what counted as women's issues at previous conferences found, to their own surprise, that most of the European and North American attendees at their sessions were in fact converts to their position (Riles 2001:182).

For their part, activists in the global South (as well as in the former Soviet Union) benefit from the transnational transfer of 'the technology to unite us' [such as...] techniques for speaking in groups, listening to each other, forming networks around a concrete issue, thinking strategically at the grassroots level about specific actions" (Sperling et al. 200I: II72). Transnational organizations help facilitate this kind of learning.

Factors external to TSMOs may also help explain the recent tendency to organize along regional as opposed to cross-regional lines. Specifically, the pattern may signal that TSMOs are finding more favorable political opportunities for affecting the issues they hope to address within more limited inter- 
Table 6: TSMO Structures

\begin{tabular}{lllll}
\hline & 1973 & 1983 & 1993 & 2000 \\
\cline { 2 - 5 } Federation & $50 \%$ & $38 \%$ & $28 \%$ & $18 \%$ \\
Coalition & 25 & 31 & 43 & 60 \\
\hline
\end{tabular}

state arenas that are defined by regional identities and interests. It may be that regional international institutions are seen as having more immediate impacts on local conditions than universal institutions like the UN, which is hampered by the diverse interests of its global membership. Or activists may have found through the experience of working at the UN that greater efforts to resolve intraregional differences (particularly within the global South) are more effective at strengthening the capacity to negotiate for regional interests within this global setting. Regional international associations may also prove more responsive and accountable to activists' demands, particularly within the relatively highly developed setting of the European Union. And factors like greater media attention to regional international negotiations as well as institutional access or geographical proximity may provide incentives for regionally based organizations. Further research is needed to determine the relative effects of external political factors and population dynamics on this organizational pattern.

The final hypothesis addressed the way the changing technologies that have fueled globalization of economic, political, and social relations have affected the structures of TSMOs. We anticipated that the comparatively greater access to inexpensive travel and communications would produce more decentralized organizational structures. Table 6 displays analyses used to test this hypothesis.

Table 6 shows some support for hypothesis 5, that TSMOs would become more decentralized in structure over time. There has been a consistent decline in the percentage of TSMOs organized as federations, that is organizations with national sections that typically share a common organization name and a more formal and centralized decision making structure. Amnesty International is a prominent example of such a group. The coalition form seems to be replacing the federation, probably because it allows more autonomy for members/participants. While they vary quite a bit in how they operate, coalitions typically allow affiliates to maintain their own organizational name and affiliation and allow more diversity in goals and strategies of affiliates. Such groups are better suited to rapid decision making at local or national levels, and they encourage innovation by members. The decentralized organizational structure allows affiliates greater flexibility as they seek to address in a local context the organization's collective goals. ${ }^{16}$
This trend towards more decentralized or network-like structures may help to explain the pattern we found in Table $\mathrm{I}$ of a declining rate of growth in the TSMO sector. The less centralized coalition structure is able to incorporate a larger number of free-standing national and sub-national groups than is the more hierarchical federal structure. Thus, while the absolute numbers of new TSMOs reveal a slowing growth rate, the level of actual participation in transnational organizations could yet be on the rise. Additional evidence about membership size is needed to assess this, and such data are not available from the Yearbook.

\section{CONCLUSIONS}

The I990s witnessed dramatic changes in the global political system as the Cold War bipolar system gave way to greater efforts at multilateral approaches to a wider range of global problems. This study explored whether and how those changes affected the patterns of transnational social movement organizing. We also examined whether structural inequalities in the world system are mirrored in the transnational social movement sector and whether this has changed in recent decades.

We might expect that the political opening created by the end of the Cold War and the related expansion of multilateral institutions during the rg9os would have encouraged an expansion in the numbers of TSMOs. While the numbers of TSMOs continued to grow between the early I990s and 2000, the rate of growth has slowed dramatically from that of recent decades. While the size of the sector more than doubled between 1983 and 1993, its growth rate was less than $50 \%$ of what it was during the I990s. This finding may be the result of greater competition for members and other resources among this growing population, or it might also reflect changes in the broader political system that served to reduce the strategic advantage of transnational organizations. It may also reflect a greater ability of transnational coalitions to absorb a larger variety of local and national organizational adherents, thereby streamlining the interest aggregation process at the global level (cf., Murphy 200I). We need more localized data to assess the meaning of this macro-level trend.

A second expectation was that the end of the Cold War would allow for an expanded international issue agenda and would alter the issue focuses of TSMOs. The most dramatic change during the I99os was that many more

16. Gamson's study (1990) found that more formal, bureaucratized and centralized organizations tended to be most effective at achieving their goals. Further research is needed to determine whether this finding applies in the contemporary global political context. 
groups are organizing around multiple-issues rather than as single-issue groups. This may reflect a greater recognition among activists of global interdependencies and of the relationships between issues such as human rights, environment, development, and peace. Certainly the opportunities for transnational communication and dialogue facilitated by transnational associational structures have helped shape these multi-issue frames. Also, the shift towards greater international trade and towards multilateral trade agreements is paralleled by an expansion in the numbers of TSMOs working on issues relating to economic justice.

Comparisons of core and periphery regions showed some important differences. We expected that periphery regions would be less integrated into TSMO memberships and that they would also have less access to intergovernmental agencies, lower levels of legitimacy, and lower survival rates. The organizational data we examine bore out some but not all of these expectations. Groups that organized in the global South only were less likely to survive between 1993 and 2000 than were groups in the North. However, groups that were organized across the North-South divide were most likely to survive, and they were also better able to establish ties with IGOs and with other actors in their environments. South-only TSMOs were also more likely than their Northern counterparts to have formal consultative status with an IGO, and they had consistently larger numbers of ties with both IGOs and NGOs. Whether these connections with external actors serve to amplify the influence Southern activists can have in the global political arena or whether they simply reduce the autonomy of such groups without giving them substantial political benefits is a question that further research should address.

Examinations of the organizing patterns of TSMOs revealed at least a leveling-off or possibly a reversal of earlier trends towards greater Southern participation in TSMOs. While earlier decades saw a growing percentage of TSMO headquarters in the global South, between 1993 and 2000 the percentage of groups based in the South declined. Similarly, the percentage of groups with members in any country of the South also declined slightly. One other finding that may have important consequences for the future course of transnational organizing is that a larger percentage of groups are organizing within regions rather than across the North-South divide. A larger percentage of new TSMOs are organized within the global North or South than was true in the past. This may create more opportunities for people to make connections between their local interests and global processes, but it could also complicate efforts to resolve the critical differences between the interests of people in the global North and South that hinder global cooperation on economic, environmental, and security issues. Further research is needed to determine how regional level organizing affects possibilities for broader, trans-regional cooperation.
Finally, we examined the ways that changing technologies have affected the organizational structures of TSMOs. The proliferation of comparatively inexpensive communication and transportation possibilities was expected to enable TSMOs to adopt more decentralized forms. This was indeed the case, and we found a shift from the more centralized federated structure towards more decentralized, coalition structures that allow TSMO affiliates greater autonomy. Future research should explore the implications of this trend for movements' success.

In short, we see some important changes in the growth and geographic makeup of the transnational social movement sector. These are likely to affect future possibilities for transnational mobilization, and in particular, the abilities of transnational groups to overcome differences in interests and culture that inhibit transnational organization, particularly across major structural divisions like core and periphery. While social movement organizations and their transnational counterparts are not the only actors in social movements, researchers have shown them to be important agenda-setters and mobilizers that provide the foundations for popular mobilizations during movement surges. Thus, efforts like this one to understand the dynamics of transnational social movement organizing can help us better explain and anticipate the course of social movements. These macro-level data offer some insights into the large-scale patterns of transnational organizing, but more localized and case study work is needed to test some of the interpretations of the data that I offer here.

\section{REFERENCES}

Amin, Samir, Andre Gunder-Frank, Immanuel Wallerstein. 1990. Transforming the Revolution: Social Movements and the World-System. New York: Monthly Review Press.

Anderson-Sherman, Arnold and Doug McAdam. 1982."American Black Insurgency and the World Economy: A Political Process Model." Pp. 165-188 in Ascent and Decline in the World System, edited by E. Friedman. Beverly Hills: Sage.

Bello, Walden. 2001. The Future in the Balance: Essays on Globalization and Resistance. Oakland: FoodFirst Books.

Bob, Clifford. 200I."Marketing Rebellion: Insurgent Groups, International Media, and NGO Support" International Politics. 38:31I-334.

Boli, John and George Thomas. 1997. "World Culture in the World Polity: A Century of Non-Governmental Organization." American Sociological Review. 62:171-190.

Boli, John and George M. Thomas, Ed. 1999. Constructing World Culture: International Nongovernmental Organizations Since 1875. Stanford:Stanford University Press.

Brysk, Allison. 1996. "Turning Weakness Into Strength: The Internationalization of Indian Rights." Latin American Perspectives. 23:38-58. 
Chabot, Sean. 2000."Transnational Diffusion and the African American Reinvention of the Gandhian Repertoire." Mobilization. 5(2):20I-216.

Chase-Dunn, Christopher and Thomas D. Hall. 1997. Rise and Demise: Comparing World Systems. Boulder: Westview Press.

Cullen, Pauline. 2003. "European NGOs and EU-Level Mobilization for Social Rights." Doctoral dissertation Thesis, Department of Sociology, State University of New York at Stony Brook.

della Porta, Donatella and Hanspeter Kriesi. 1999. "Social Movements in a Globalizing World: An Introduction." Pp. 3-23 in Social Movements in a Globalizing World, edited by D. della Porta, H. Kriesi, and D. Rucht. New York: St. Martin's Press.

Edwards, Bob and Sam Marullo. 1995. "Organizational Mortality in a Declining Movement: The Demise of Peace Movement Organizations in the End of the Cold War Era." American Sociological Review. 60:805-825.

Evangelista, Matthew. 1995."The Paradox of State Strength: Transnational Relations, Domestic Structures and Security Policy in Russia and the Soviet Union." International Organization. 49:1-38.

Finnemore, Martha. 1996. National Interests in International Society. Ithaca, NY: Cornell University Press.

Fox, Jonathan and L. David Brown. 1998. The Struggle for Accountability: The World Bank, NGOs, and Grassroots Movements. Cambridge: MIT Press.

Friedman, Elisabeth Jay, Ann Marie Clark, and Kathryn Hochstetler. Forthcoming. The Sovereign Limits of Global Civil Society.

Guidry, John A., Michael D. Kennedy, and Mayer N. Zald. Forthcoming. "Globalizations and Social Movements." Chapter I in Introduction: Globalizations and Social Movements, edited by J. A. Guidry, M. D. Kennedy, and M. N. Zald.

Gamson, William. 1990. Strategy of Social Protest, Second Edition. Belmont, CA: Wadsworth.

Hannan, Michael T. and John Freeman. 1977."The Population Ecology of Organizations." American Journal of Sociology. 82:929-64.

Hovey, Michael. 1997. "Interceding at the United Nations: The Right of Conscientious Objection." in Transnational Social Movements and Global Politics: Solidarity Beyond the State, edited by J. Smith, C. Chatfield, and R. Pagnucco. Syracuse, NY: Syracuse University Press.

Keck, Margaret. 1998. "Environmental Advocacy Networks." Pp. 12I-163 in Activists Beyond Borders, edited by M. E. Keck and K. Sikkink. Ithaca: Cornell University Press.

Keck, Margaret and Kathryn Sikkink. 1998. Activists Beyond Borders: Advocacy Networks in International Politics. Ithaca: Cornell University Press.

Khagram, Sanjeev, James V. Riker, and Kathryn Sikkink. 2002. Restructuring World Politics: Transnational Social Movements, Networks, and Norms. Minneapolis: University of Minnesota Press.

Korzeniewicz, Robert Patricio and Timothy Patrick Moran. 1997. "World-Economic Trends in the Distribution of Income 1965-1992." American Journal of Sociology. I02:1000-1039.
Exploring Connections Between Global Integration

Kriesberg, Louis. 1997. “Social Movements and Global Transformation.” Pp. 3-18 in Transnational Social Movements and World Politics: Solidarity Beyond the State, edited by J. Smith, C. Chatfield, and R. Pagnucco. Syracuse, NY: Syracuse University Press.

Kumar. 1992. Raising Up a Prophet: The African-American Encounter with Gandhi. Boston: Beacon Press.

Macdonald, Laura. 1997. Supporting Civil Society: The Political Role of Non-Governmental Organizations in Central America. New York: St. Martin's Press.

Maney, Gregory M. 2002."Transnational Structures and Protest: Linking Theories and Assessing Evidence." Pp.3I-50 in Globalization and Resistance: Transnational Dimensions of Social Movements, edited by J. Smith and H. Johnston. Lanham, Md.: Rowman \& Littlefield.

Markoff, John. 1996. Waves of Democracy: Social Movements and Political Change. Thousand Oaks: Pine Forge Press.

Markoff, John. 1999. "Globalization and the Future of Democracy. Journal of WorldSystems Research. 5:242-262. http://jwsr.ucr.edu/

McAdam, Doug, John D. McCarthy, and Mayer Zald, Ed. 1996. Comparative Perspectives on Social Movements: Political Opportunities, Mobilizing Structures and Cultural Framings. New York, NY: Cambridge University Press.

McAdam, Doug and Dieter Rucht. 1993. "The Cross-National Diffusion of Movement Ideas." The Annals of the American Academy of Political and Social Science. 528:5674.

McCarthy, John D. 1997. "The Globalization of Social Movement Theory." Pp. 243-259 in Transnational Social Movements and World Politics: Solidarity Beyond the State, edited by J. Smith, C. Chatfield, and R. Pagnucco. Syracuse, NY: Syracuse University Press.

McCarthy, John D. and Mayer Zald. 1977. "Resource Mobilization in Social Movements: A Partial Theory" American Journal of Sociology. 82:I2I2-4I.

Meyer, John W., David John Frank, Ann Hironaka, Evan Schofer, and Nancy Brandon Tuma. 1997. "The Structuring of a World Environmental Regime, 1870-1990." International Organization. 51:623-65I.

Michaelson, Marc. 1994. "Wangari Maathai and Kenya's Green Belt Movement: Exploring the Evolution and Potentialities of Consensus Movement Mobilization." Social Problems. 41:540-56I.

Minkoff, Deborah. 1995. Organizing for Equality: the Evolution of Women's and Racial Ethnic Organizations in America, 1955-1985. New Brunswick, NJ: Rutgers University Press.

Murphy, Gillian Hughs, 2002. "A Double-Edged Sword: Coalitions and the Development of the Global Environmental Movement." M.A. Thesis, Sociology, University of Washington, Seattle, WA.

Price, Richard. 1998. "Reversing the Gun Sights: Transnational Civil Society Targets Land Mines." International Organization. 52(3):613-644.

Riles, Annelise. 200I. The Network Inside Out. Ann Arbor: University of Michigan Press. 
Risse-Kappen, Thomas. 1995. "Bringing Transnational Relations Back In: Introduction." Pp. 3-33 in Bringing Transnational Relations Back In: Non-State Actors, Domestic Structures, and International Institutions, edited by T. Risse-Kappen. New York: Cambridge University Press.

Risse, Thomas. 2000."Transnational Actors, Networks and Global Governance." in Handbook of International Relations, edited by W. Carlsnaes, T. Risse, and B. Simmons, London: Sage.

Risse, Thomas, Stephen C. Ropp, and Kathryn Sikkink, Ed. 1999. The Power of Human Rights: International Norms and Domestic Change. New York: Cambridge University Press.

Rothman, Franklin Daniel and Pamela E. Oliver. 2002. "From Local to Global: The Anti-Dam Movement in Southern Brazil 1979-1992," in Globalization and Resistance: Transnational Dimensions of Social Movements, edited by J. Smith and H. Johnston. Lanham, Md.: Rowman \& Littlefield.

Sassen, Saskia. 1991. The Global City: New York, London, Tokyo. Princeton: Princeton University Press.

Sassen, Saskia. 1998. Globalization and its Discontents. New York: The New Press.

Sikkink, Kathryn. and Jackie Smith 2002. "Infrastructures for Change: Transnational Organizations, 1953-1993." Pp. 24-44 in Restructuring World Politics: The Power of Transnational Agency and Norms, edited by Sanjeev Khagram, James Riker and Kathryn Sikkink. Minneapolis: University of Minnesota Press.

Sklair, Leslie. 200I. The Transnational Capitalist Class. Cambridge: Blackwell.

Skocpol, Theda. 1979. States and Social Revolutions: A Comparative Analysis of France, Russia and China. New York: Cambridge University Press.

Smith, Jackie. 1995. "Transnational Political Processes and the Human Rights Movement." Pp. 185-220 in Research in Social Movements, Conflict and Change, vol. I8, edited by L. Kriesberg, M. Dobkowski, and I. Walliman. Greenwood CT: JAI.

Smith, Jackie, Ron Pagnucco, and Charles Chatfield. 1997."Transnational Social Movements and World Politics: Theoretical Framework." Pp. 59-77 in Transnational Social Movements and Global Politics: Solidarity Beyond the State, edited by J. Smith, C. Chatfield, and R. Pagnucco. Syracuse: Syracuse University Press.

Smith, Jackie. 2002a."Globalizing Resistance: The Battle of Seattle and the Future of Social Movements." Pp. 183-199 in Globalization and Resistance: Transnational Dimensions of Social Movements, edited by J. Smith and H. Johnston. Lanham, Md.: Rowman \& Littlefield.

Smith, Jackie. 2002b."Bridging Global Divides?: Strategic Framing and Solidarity in Transnational Social Movement Organizations." International Sociology. I7(4).

Snow, David, E.B. Rochford, S. Warden, and Robert Benford. 1986. "Frame Alignment Processes, Micromobilization and Movement Participation." American Sociological Review. 51:273-286.

Sperling, Valerie, Myra Marx Feree, and Barbara Risman. 20oI. "Constructing Global Feminism: Transnational Advocacy Networks and Russian Women's Activism." Signs: Journal of Women in Culture and Society 26:1155-1186.
Tarrow, Sidney. 1998. Power in Movement, 2nd Edition. New York: Cambridge University Press.

Tarrow, Sidney. 200I."Transnational Politics: Contention and Institutions in International Politics." Annual Review of Political Science. 4:I-20.

Tilly, Charles. 1984. "Social Movements and National Politics." Pp. 297-317 in Statemaking and Social Movements: Essays in History and Theory, edited by C. Bright and S. Harding. Ann Arbor: University of Michigan Press.

Union of International Associations. Annual. Yearbook of International Organizations. Brussels: Union of International Associations.

Wolf, Eric. 1982. Europe and the People Without History. Berkeley: University of California Press.

Warkentin, Craig. 200I. Reshaping World Politics: NGOs, the Internet, and Global Civil Society. New York: Rowman and Littlefield.

Walton, John and David Seddon. 1994. Free Markets and Food Riots: The Politics of Global Adjustment. Cambridge, MA: Blackwell. 